\title{
Perinatal and childhood factors and risk of breast cancer subtypes in adulthood
}

Virginia Lope ${ }^{a, b, c}$, Esther García-Esquinas ${ }^{\mathrm{d}, \mathrm{b}}$, Beatriz Pérez-Gómez ${ }^{\mathrm{a}, \mathrm{b}, \mathrm{c}}$, Jone M. Altzibar ${ }^{\mathrm{e}, \mathrm{f}, \mathrm{b}}$, Esther GraciaLavedan $^{g, h, b}$, María Ederra ${ }^{\mathrm{i}, \mathrm{j}, \mathrm{b}}$, Antonio Jose Molina de la Torre ${ }^{k}$, Francisco Javier LLorca,b, Adonina Tardón ${ }^{\mathrm{m}, \mathrm{b}}$, Víctor Moreno ${ }^{n, o, b}$, Juan Bayo ${ }^{p, q}$, Dolores Salas-Trejor, Rafael Marcos-Grageras, José 'Pumaregat, Trinidad Dierssen-Sotos $^{\mathrm{l}, \mathrm{b}}$, Juan Pablo Barrio Lera ${ }^{\mathrm{k}}, \mathrm{M}^{\mathrm{a}}$ Concepción de Miguel Medina ${ }^{\mathrm{j}, \mathrm{u}}$, Ignasi Tusquets ${ }^{\mathrm{v}, \mathrm{w}, \mathrm{x}}$, Pilar Amiano $^{\mathrm{e}, \mathrm{f}, \mathrm{b}}$, Elena Boldo ${ }^{\mathrm{a}, \mathrm{b}, \mathrm{c}}$, Manolis Kogevinas ${ }^{\mathrm{g}, \mathrm{y}, \mathrm{h}, \mathrm{b}}$, Nuria Aragonés ${ }^{\mathrm{a}, \mathrm{b}, \mathrm{c}}$, Gemma Castaño-Vinyals ${ }^{\mathrm{g}, \mathrm{y}, \mathrm{h}, \mathrm{b}}$, Marina Pollán ${ }^{a, b, c}$

a Cancer and Environmental Epidemiology Unit, National Center for Epidemiology, Carlos III Institute of Health. Avenida Monforte de Lemos 5, 28029, Madrid, Spain.

${ }^{b}$ Consortium for Biomedical Research in Epidemiology and Public Health (CIBER Epidemiología y Salud Pública, CIBERESP), Spain.

${ }^{c}$ Cancer Epidemiology Research Group. Oncology and Hematology Area. IIS Puerta de Hierro (IDIPHIM). Manuel de Falla 1. 28222, Madrid, Spain.

${ }^{\mathrm{d}}$ Department of Preventive Medicine and Public Health, School of Medicine, Universidad Autónoma de Madrid / IdiPaz.

Arzobispo Morcillo 4, 28029, Madrid, Spain.

e Public Health Division of Gipuzkoa. Avenida de Navarra 4, 20013 Donostia, San Sebastián, Spain.

${ }^{\dagger}$ Biodonostia Research Institute. Doctor Begiristain s/n, 20014. Donostia, San Sebastián, Spain.

${ }^{9}$ Centre for Research in Environmental Epidemiology (CREAL). Doctor Aiguader 88, 08003, Barcelona, Spain.

h Universitat Pompeu Fabra (UPF). Doctor Aiguader 88, 08003, Barcelona, Spain.

'Early Detection Section. Public Health Institute of Navarra. Leyre 15, 31003, Pamplona, Spain.

j Navarra Institute for Health Research (IdiSNA). Irunlarrea 3, 31008, Pamplona, Spain.

${ }^{k}$ Grupo de Investigación en Interacciones Gen-Ambiente y Salud. Universidad de León. 24071, León, Spain.

' Universidad de Cantabria-IDIVAL. Avenida Cardenal Herrera Oria s/n, 39011, Santander, Spain.

m Instituto Universitario de Oncología, Universidad de Oviedo. Facultad de Medicina, Planta 7, Campus de El Cristo B, 33006, Oviedo, Asturias, Spain..

${ }^{n}$ IDIBELL-Catalan Institute of Oncology. Gran Via km 2.7, 08907, L'Hospitalet de Llobregat, Spain.

- Department of Clinical Sciences, Faculty of Medicine, University of Barcelona. Campus de Bellvitge, Pavelló de Govern, Feixa Llarga s/n 08907, L'Hospitalet del Llobregat, Barcelona, Spain.

p Servicio de Oncología Médica. Hospital Juan Ramón Jiménez. Avenida de la Orden s/n, 21005, Huelva, Spain.

a Centro de Investigación en Salud y Medio Ambiente (CYSMA), Universidad de Huelva. Campus Universitario de El Carmen. 21071, Huelva, Spain.

${ }^{r}$ General Directorate Public Health, and FISABIO. Avenida. de Catalunya, 21, 46020, Valencia, Spain.

${ }^{s}$ Epidemiology Unit and Girona Cancer Registry, Oncology Coordination Plan, Department of Health, Autonomous Government of Catalonia, Catalan Institute of Oncology, Girona Biomedical Research Institute (IdiBGi). Carrer del Sol 15, 17004, Girona, Spain.

${ }^{t}$ Grup de Recerca en Epidemiologia Clínica i Molecular del Càncer (GRECMC). Hospital del Mar Medical Research Institute (IMIM). Doctor Aiguader 88, 08003, Barcelona, Spain.

${ }^{u}$ Pathology Department. Navarra Hospital Complex. Irunlarrea 3, 31008, Pamplona, Spain.

$\checkmark$ Servei d'Oncologia Mèdica, Hospital del Mar. Passeig Marítim 25-29, 08003, Barcelona, Spain.

w Cancer Research Program IMIM (Hospital del Mar Medical Research Institute). Doctor Aiguader 88, 08003, Barcelona, Spain.

x Universitat Autònoma de Barcelona. Plaza Cívica s/n, 08193 Bellaterra, Barcelona, Spain.

${ }^{y}$ IMIM (Hospital del Mar Medical Research Institute). Doctor Aiguader 88, 08003, Barcelona, Spain.

\section{Corresponding author:}

Virginia Lope

Cancer and Environmental Epidemiology Unit

National Center for Epidemiology

Carlos III Institute of Health

Avda. Monforte de Lemos, 5, 28029 Madrid, Spain

Tel.: +34-918222640

Fax: +34-91-3877815

E-mail:vicarvajal@isciii.es 


\section{Abstract \\ Background}

Accumulated exposure to hormones and growth factors during early life may influence the future risk of breast cancer (BC). This study examines the influence of childhood-related, socio-demographic and anthropometric variables on $\mathrm{BC}$ risk, overall and by specific pathologic subtypes.

\section{Methods}

This is a case-control study where 1539 histologically-confirmed BC cases (23-85 years) and 1621 population controls, frequency matched by age, were recruited in 10 Spanish provinces. Perinatal and childhood-related characteristics were directly surveyed by trained staff. The association with BC risk, globally and according to menopausal status and pathologic subtypes, was evaluated using logistic and multinomial regression models, adjusting for tumor specific risk factors.

\section{Results}

Birth characteristics were not related with BC risk. However, women with high socioeconomic level at birth presented a decreased $B C$ risk $(O R=0.45 ; 95 \% C l=0.29-0.70)$, while those whose mothers were aged over 39 years at their birth showed an almost significant excess risk of hormone receptor positive tumors $(H R+)(O R=1.35$; $95 \% \mathrm{Cl}=0.99-1.84)$. Women who were taller than their girl mates before puberty showed increased postmenopausal $\mathrm{BC}$ risk $(\mathrm{OR}=1.26 ; 95 \% \mathrm{Cl}=1.03-1.54)$ and increased $\mathrm{HR}+\mathrm{BC}$ risk $(\mathrm{OR}=1.26 ; 95 \% \mathrm{Cl}=1.04-1.52)$. Regarding prepubertal weight, while those women who were thinner than average showed higher postmenopausal BC risk $(\mathrm{OR}=1.46 ; 95 \% \mathrm{Cl}=1.20-1.78)$, associated with $\mathrm{HR}+$ tumors $(\mathrm{OR}=1.34 ; 95 \% \mathrm{Cl}=1.12-1.61)$ and with triple negative tumors $(\mathrm{OR}=1.56 ; 95 \% \mathrm{Cl}=1.03-2.35)$, those who were heavier than average presented lower premenopausal $\mathrm{BC}$ risk $(\mathrm{OR}=0.64 ; 95 \% \mathrm{Cl}=0.46-0.90)$ and lower risk of epidermal growth factor receptor positive tumors $(\mathrm{OR}=0.61$; $95 \% \mathrm{Cl}=0.40-0.93)$.

\section{Conclusion}

These data reflect the importance of hormones and growth factors in the early stages of life, when the mammary gland is in development and therefore more vulnerable to proliferative stimuli.

Keywords: breast cancer subtypes, childhood factors, perinatal factors, early life factors, case-control study, Spain, hormone receptor, maternal age, childhood height, childhood weight. 


\section{Introduction}

Breast cancer $(B C)$ is the most frequent cause of cancer in Spanish women, with more than 25,200 new cases diagnosed per year [1]. During the last decades of the 20th century, it showed a steady increase in incidence, even among women younger than 45 years, though trends seem to level off in 2001 [2] . It is also the tumor with the highest mortality rate in Spanish women, accounting for 15.6\% of all female cancer-related deaths in 2013 [3].

The intrauterine environment may influence the subsequent risk of $B C$ in female offspring. Endogenous pregnancy hormones can act as growth factors increasing the stem cell population (and thereby the size of the organ and the number of susceptible stem cells later in life) or inducing cell proliferation. In so doing, these hormones increase the risk for genetic errors (oncogenic mutations or spontaneous somatic mutations), as well as the expansion of initiated clones. Additionally, estrogens and their metabolites can also act as genotoxic agents $[4,5]$. Epidemiologic studies have shown moderate positive associations of BC risk with birthweight, birth length, maternal age and twin pregnancies; in contrast, pre-eclampsia or eclampsia seem to be inversely associated with the risk of this tumor [69].

Puberty is also a critical period for mammary gland development. Just before puberty, an exponential growth of the mammary gland, characterized by formation of terminal end buds, begins. These structures are considered the most vulnerable targets for carcinogens, and are still abundant during adolescence [10,11]. There are studies that have described a positive relationship between BC risk and childhood height or height velocity as well as an inverse association with childhood obesity or body mass index (BMI) velocity [12-16].

$\mathrm{BC}$ represents a heterogeneous disease, and its risk factors vary by molecular-based BC subtypes [17, 18]. This study sought to investigate whether perinatal and childhood sociodemographic and anthropometric factors influence the risk of BC in adulthood, using a large population-based case control study in Spain. In addition, we also assessed whether these associations differed by specific BC subtypes.

\section{Materials and Methods}

\subsection{Study population}

Multicase Control Spain (MCC-Spain) is a case-control study with population controls and incident cases treated in the oncologic units of 23 hospitals located in 12 Spanish provinces (Barcelona, Madrid, Navarra, Gipuzkoa, León, 
Asturias, Murcia, Huelva, Cantabria, Valencia, Granada and Girona). It was carried out with the purpose to evaluate environmental and genetic factors associated with the risk of colorectal, breast, prostate, gastric tumors and chronic lymphocytic leukemia. Inclusion criteria required that participants had lived for at least 6 months in the study areas, were between 20-85 years old and were able to answer the epidemiological questionnaire. Given the hospitals and the resources available to us, the initial intention was to collect at least 1500 breast, 1500 colorectal cancer cases, 1000 prostate cancer cases, 500 gastric cancer cases and 500 chronic lymphocytic leukemias. Cases were identified as soon as possible after their diagnosis, through active search that included hospital admission registries and periodical visits to the collaborating hospital departments (i.e. gynecology, oncology, general surgery, radiotherapy and pathology departments, and breast cancer multidisciplinary units). Between September 2008 and December 2013 we recruited a total of 1738 histologically-confirmed BC cases (ICD-10: C50, D05.1, D05.7) with complete interviews and informed consent in 10 of these provinces (all except Murcia and Granada).

Population controls were randomly selected from the general practitioner lists of the hospital catchment area and were frequency matched to cases by age, sex and region, ensuring that in each region there was at least one control of the same sex and 5-year interval for each case. Participants were contacted by telephone, and those who agreed to participate signed an informed consent. We recruited a total of 1910 female controls. The study was approved by the Ethics Committee of all hospitals and participant primary care centers. Fig.1 show a flow chart displaying the selection process of breast cancer cases and controls. More details regarding the design of the study are provided elsewhere [19].

Fig.1: Flow chart displaying the selection process of breast cancer cases and controls. MCC-Spain study 20082013. 


\section{CASES}

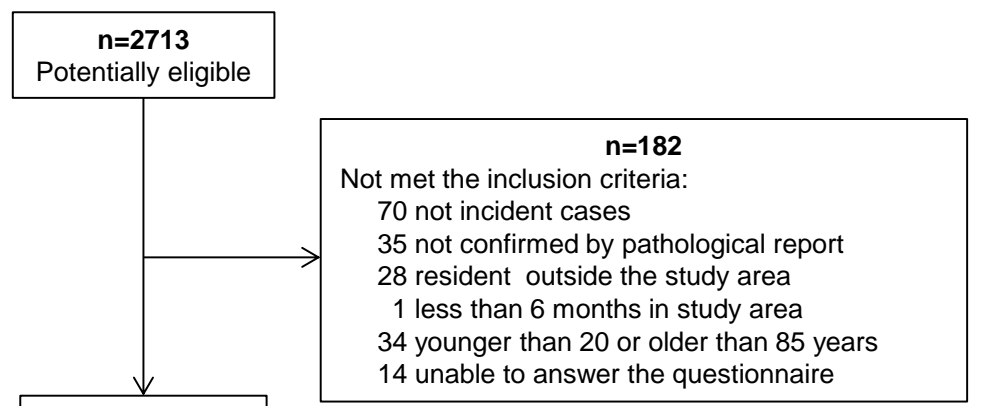

Eligible cases

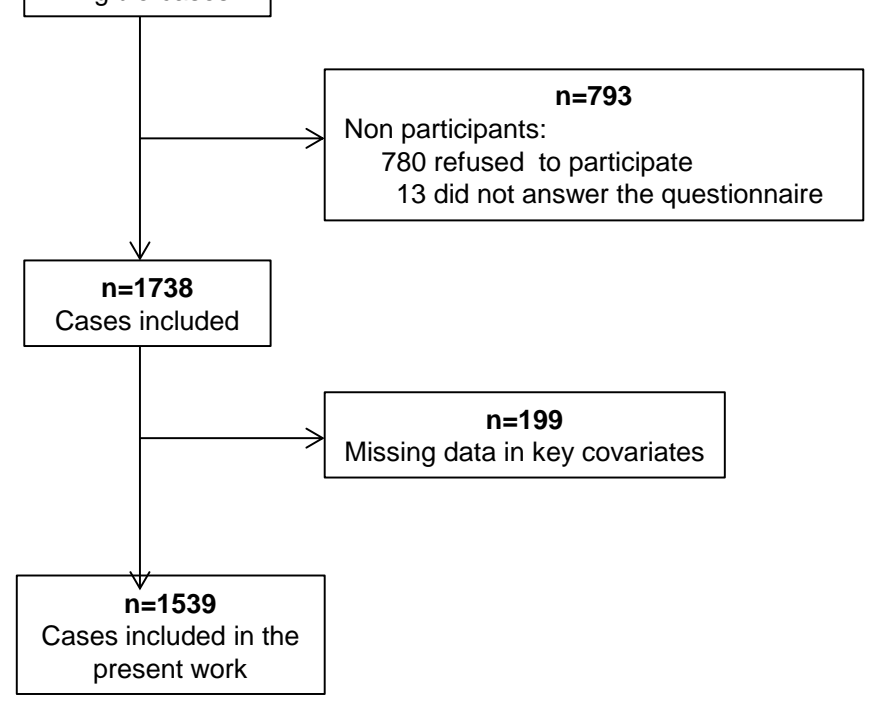

\section{CONTROLS}

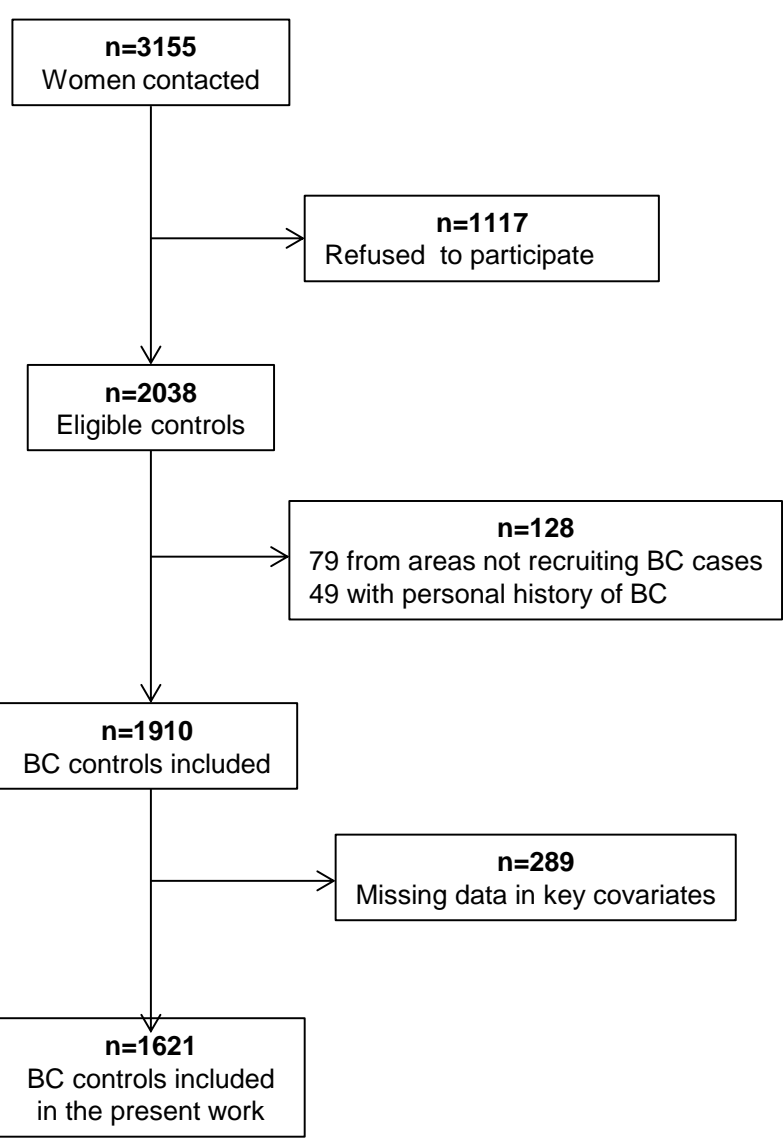

\subsection{Data collection}

Trained interviewers administered a structured computerized epidemiological questionnaire in a face-to-face interview. This questionnaire recorded sociodemographic and anthropometric data, family and personal history, gynecological, obstetric, medical, residential and occupational history, smoking and physical activity. Finally cases and controls completed a validated food frequency questionnaire. With respect to perinatal factors, the questionnaire collected information on socioeconomic level at birth (income of their parents when the women were born), maternal and paternal age at birth, birthweight, birth order and premature birth. With respect to childhood factors, the questionnaire collected information about how women were before having their first menstruation in comparison with their girl mates (heavier than average; average; thinner than average or taller than average; average; shorter than average) and age at menarche.

\subsection{Breast cancer subtypes}


Trained personnel reviewed all pathology records and registered information regarding estrogen receptor (ER), progesterone receptor (PR) and the human epidermal growth factor receptor (HER2) in BC cases. So, BC cases were sub classified by the following subtypes: hormone receptor positive tumors $(H R+)(E R+$ or PR+ with HER2-), HER2+ tumors (independent of ER or PR) and triple negative (TN) tumors (ER-, PR- and HER2-).

\subsection{Statistical analyses}

Descriptive analyses of participants' characteristics were performed for cases and controls. Categorical variables were described using absolute figures and percentages, and continuous variables using means and standard deviations. Significant differences between cases and controls were tested using Pearson chi-square for categorical variables and Student's t-test for continuous variables assuming equal variances.

The association of perinatal and childhood variables with BC risk was evaluated using logistic mixed regression models, including the province as a random effect term, as implemented in Stata's gllamm command [20]. Models were adjusted for age, educational level, BMI one year before the interview, age at first birth, age at menarche, previous biopsies, family history of BC and menopausal status. We also conducted stratified analyses by menopausal status. Heterogeneity of effects among pre and postmenopausal women were assessed, including an interaction term between menopausal status and the corresponding variable of interest.

Finally, multinomial logistic regression models were used to evaluate the association of perinatal and childhood factors with each of the above-mentioned BC subtypes. These models were adjusted by the same set of variables described above, including the province as a random effect term. Heterogeneity of effects was tested using a Wald test comparing the coefficients obtained for the different cancer subtypes. All analyses were performed in STATA/MP 13.1 software.

\section{Results}

Response rates were $53.8 \%$ for healthy female controls and $68.7 \%$ for $\mathrm{BC}$ cases. Results presented in this manuscript are based on participants with no missing values in any of the selected confounders: $1539 \mathrm{BC}$ cases (89\%) and 1621 controls (85\%). Table 1 shows the main characteristics of this population. In general, cases were slightly younger and had fewer children than controls. A sensitivity analysis testing the distribution of these variables in cases and controls excluded due to lack of information on any of the selected confounders showed similar results to those obtained here (data not shown). 
Table 1: Socio-demographic characteristics of breast cancer cases and controls

\begin{tabular}{|c|c|c|c|}
\hline & $\begin{array}{l}\text { BC cases } \\
(\mathrm{N}=1539)\end{array}$ & $\begin{array}{l}\text { Controls } \\
(\mathrm{N}=1621)\end{array}$ & p-val \\
\hline Age, mean(SD) & $56.0(12.1)$ & $58.2(12.7)$ & $<0.001$ \\
\hline \multicolumn{4}{|l|}{ Educational level, N(\%) } \\
\hline less than primary school & $215(14 \%)$ & $235(14 \%)$ & \\
\hline primary school completed & $504(33 \%)$ & $489(30 \%)$ & \\
\hline secondary school & $512(33 \%)$ & $521(32 \%)$ & \\
\hline university graduate & $308(20 \%)$ & $376(23 \%)$ & 0.120 \\
\hline \multicolumn{4}{|l|}{$\mathrm{BMI}, \mathrm{N}(\%)$} \\
\hline$<20 \mathrm{Kg} / \mathrm{m}^{2}$ & $88(6 \%)$ & $114(7 \%)$ & \\
\hline $20-24 \mathrm{Kg} / \mathrm{m}^{2}$ & $636(41 \%)$ & $710(44 \%)$ & \\
\hline $25-29 \mathrm{Kg} / \mathrm{m}^{2}$ & $528(34 \%)$ & $509(31 \%)$ & \\
\hline$>29 \mathrm{Kg} / \mathrm{m}^{2}$ & $287(19 \%)$ & $288(18 \%)$ & 0.130 \\
\hline \multicolumn{4}{|l|}{ Menopausal status, $\mathrm{N}(\%)$} \\
\hline premenopausal & $540(35 \%)$ & $485(30 \%)$ & \\
\hline peri-postmenopausal & $999(65 \%)$ & $1136(70 \%)$ & 0.002 \\
\hline \multicolumn{4}{|l|}{ Number of children, $\mathrm{N}(\%)$} \\
\hline none & $311(20 \%)$ & $308(19 \%)$ & \\
\hline $1-2$ & $904(59 \%)$ & $907(56 \%)$ & \\
\hline $3-4$ & $284(18 \%)$ & $341(21 \%)$ & \\
\hline$>4$ & $40(3 \%)$ & $65(4 \%)$ & 0.029 \\
\hline Age at first birth, mean(SD) & $26.7(4.9)$ & $26.7(4.8)$ & 0.939 \\
\hline Age at menarche, mean(SD) & $12.8(1.6)$ & $12.8(1.6)$ & 0.139 \\
\hline \multicolumn{4}{|l|}{ Previous biopsies, $\mathrm{N}(\%)$} \\
\hline none & $1420(92 \%)$ & $1585(98 \%)$ & \\
\hline yes & $119(8 \%)$ & $36(2 \%)$ & $<0.001$ \\
\hline \multicolumn{4}{|c|}{ Family history of breast cancer, $\mathrm{N}(\%)$} \\
\hline none & $1152(75 \%)$ & $1386(86 \%)$ & \\
\hline second degree only & $161(10 \%)$ & $91(6 \%)$ & \\
\hline 1 first degree & $197(13 \%)$ & $134(8 \%)$ & \\
\hline$>1$ first degree & $29(2 \%)$ & $10(1 \%)$ & $<0.001$ \\
\hline
\end{tabular}

Table 2 shows the association between BC and perinatal and childhood factors, both globally and stratified by menopausal status. Although the number of cases was low, pre and postmenopausal women with high socioeconomic level at birth showed a decreased risk of $B C(O R=0.45 ; 95 \% \mathrm{Cl}=0.29-0.70)$. Those women whose mother was aged over 39 years at their birth displayed greater BC risk (OR:1.30;95\% $\mathrm{Cl}=0.98-1.73)$, although this result failed to attain statistical significance. Participants who reported being thinner than average during their prepubertal period showed an increased risk of $\mathrm{BC}(\mathrm{OR}=1.34 ; 95 \% \mathrm{Cl}=1.14-1.57)$, and this association was stronger among postmenopausal women $(\mathrm{OR}=1.46 ; 95 \% \mathrm{Cl}=1.20-1.78)$. By contrast, those who reported being heavier than average during childhood showed decreased premenopausal $\mathrm{BC}$ risk (OR=0.64; $95 \% \mathrm{Cl}=0.46-0.90)$. Higher prepubertal height was also associated with greater risk of postmenopausal $B C(O R=1.26 ; 95 \% \mathrm{Cl}=1.03$ 1.54). 
Table 3 summarizes these results by BC tumor subtypes. In general, $66 \%$ of $\mathrm{BC}$ cases were $\mathrm{HR}+, 17 \%$ were HER2+ and 8\% were TN tumors (similar to percentages described by another Spanish population-based study [21]. We could not classify 137 (9\%) BC cases. The inverse association with socioeconomic level at birth was mainly confirmed for HR+ tumors, although, again, the number of cases in the high socioeconomic level was very low. The increased risk associated with advanced maternal age was almost significant for HR+ tumors (OR $>39$ years $=1.35 ; 95 \% \mathrm{Cl}=0.99-1.84)$. Women who were taller than average in their prepubertal period also showed an increased risk of $\mathrm{HR}+$ tumors $(\mathrm{OR}=1.26 ; 95 \% \mathrm{Cl}=1.04-1.52)$. Finally, with regard to prepubertal weight, those women who were thinner than average showed increased risk of $\mathrm{HR}+(\mathrm{OR}=1.34 ; 95 \% \mathrm{Cl}=1.12-1.61)$ and $\mathrm{TN}$ tumors $(\mathrm{OR}=1.56 ; 95 \% \mathrm{Cl}=1.03-2.35)$ while those who were heavier presented lower HER2+ $\mathrm{BC}$ risk $(\mathrm{OR}=0.61$; $95 \% \mathrm{Cl}=0.40-0.93)$.

We didn't find any significant association with other perinatal or childhood variables, such as paternal age at birth, firstborn baby, premature birth, birth weight or age at menarche. 
Table 2: Association between birth and childhood characteristics and breast cancer risk, both overall and broken down by menopausal status

\begin{tabular}{|c|c|c|c|c|c|c|c|c|c|c|c|c|c|c|c|c|c|c|c|}
\hline \multirow{3}{*}{ Socio-economic level at } & \multicolumn{6}{|c|}{ All women $(\mathrm{N}=3160)$} & \multicolumn{6}{|c|}{ Pre-menopausal women $(\mathrm{N}=1025)$} & \multicolumn{6}{|c|}{ Post-menopausal women ( $\mathrm{N}=2135)$} & \multirow[b]{2}{*}{ P-int. $^{b}$} \\
\hline & Cases & \multirow[t]{2}{*}{ controls } & \multirow[t]{2}{*}{$\mathbf{O R}^{\mathrm{a}}$} & \multicolumn{2}{|c|}{$95 \% \mathrm{Cl}$} & \multirow[t]{2}{*}{$\mathbf{P}$} & \multirow[t]{2}{*}{ Cases } & \multirow[t]{2}{*}{ controls } & \multirow[t]{2}{*}{$\mathrm{OR}^{\mathrm{a}}$} & \multicolumn{2}{|c|}{$95 \% \mathrm{Cl}$} & \multirow[t]{2}{*}{$\mathbf{P}$} & \multirow[t]{2}{*}{ Cases } & \multirow[t]{2}{*}{ controls } & \multirow[t]{2}{*}{$\mathbf{O R}^{\mathbf{a}}$} & & $5 \% \mathrm{Cl}$ & $\mathbf{P}$ & \\
\hline & & & & & & & & & & & & & & & & & & & \\
\hline low & 489 & 533 & 0.94 & 0.80 & -1.11 & 0.477 & 131 & 117 & 0.97 & 0.72 & -1.30 & 0.818 & 358 & 416 & 0.93 & 0.77 & -1.13 & 0.481 & \\
\hline middle & 1017 & 1007 & 1.00 & & & & 398 & 343 & 1.00 & & & & 619 & 664 & 1.00 & & & & \\
\hline high & 30 & 78 & 0.45 & 0.29 & - 0.70 & $<0.001$ & 10 & 23 & 0.42 & 0.19 & -0.91 & 0.027 & 20 & 55 & 0.46 & 0.27 & -0.80 & 0.005 & 0.956 \\
\hline Maternal age at birth & & & & & & & & & & & & & & & & & & & \\
\hline$<30$ years & 708 & 793 & 1.00 & & & & 258 & 252 & 1.00 & & & & 450 & 541 & 1.00 & & & & \\
\hline $30-34$ years & 388 & 369 & 1.13 & 0.94 & -1.35 & 0.184 & 157 & 116 & 1.27 & 0.93 & -1.72 & 0.129 & 231 & 253 & 1.06 & 0.85 & -1.33 & 0.603 & \\
\hline $35-39$ years & 194 & 208 & 1.01 & 0.80 & -1.26 & 0.949 & 71 & 65 & 1.07 & 0.73 & -1.58 & 0.723 & 123 & 143 & 0.97 & 0.74 & -1.29 & 0.858 & \\
\hline$>39$ years & 136 & 110 & 1.30 & 0.98 & -1.73 & 0.066 & 40 & 29 & 1.28 & 0.76 & -2.15 & 0.358 & 96 & 81 & 1.31 & 0.94 & -1.82 & 0.116 & \\
\hline five-year trend & & & 1.04 & 0.98 & -1.11 & 0.174 & & & 1.06 & 0.95 & -1.17 & 0.310 & & & 1.04 & 0.96 & -1.11 & 0.339 & 0.819 \\
\hline Paternal age at birth ${ }^{c}$ & & & & & & & & & & & & & & & & & & & \\
\hline$<30$ years & 451 & 516 & 1.00 & & & & 165 & 170 & 1.00 & & & & 286 & 346 & 1.00 & & & & \\
\hline $30-34$ years & 410 & 408 & 1.07 & 0.87 & -1.32 & 0.509 & 152 & 124 & 1.19 & 0.85 & -1.67 & 0.321 & 258 & 284 & 1.02 & 0.79 & -1.31 & 0.871 & \\
\hline $35-39$ years & 268 & 240 & 1.18 & 0.90 & -1.55 & 0.238 & 116 & 79 & 1.43 & 0.96 & -2.13 & 0.078 & 152 & 161 & 1.06 & 0.76 & -1.46 & 0.736 & \\
\hline$>39$ years & 266 & 280 & 0.98 & 0.70 & -1.37 & 0.905 & 84 & 82 & 0.96 & 0.61 & -1.52 & 0.871 & 182 & 198 & 0.99 & 0.69 & -1.42 & 0.948 & \\
\hline five-year trend & & & 1.00 & 0.91 & - 1.09 & 0.936 & & & 1.02 & 0.90 & -1.14 & 0.788 & & & 0.99 & 0.90 & -1.09 & 0.793 & 0.534 \\
\hline Firstborn baby & & & & & & & & & & & & & & & & & & & \\
\hline no & 1111 & 1153 & 1.00 & & & & 392 & 348 & 1.00 & & & & 719 & 805 & 1.00 & & & & \\
\hline yes & 413 & 449 & 1.00 & 0.85 & -1.17 & 0.971 & 145 & 133 & 1.02 & 0.77 & -1.35 & 0.906 & 268 & 316 & 1.00 & 0.81 & -1.20 & 0.899 & 0.865 \\
\hline Premature baby & & & & & & & & & & & & & & & & & & & \\
\hline no & 1423 & 1522 & 1.00 & & & & 502 & 456 & 1.00 & & & & 921 & 1066 & 1.00 & & & & \\
\hline yes & 72 & 65 & 1.14 & 0.80 & -1.63 & 0.456 & 24 & 26 & 0.75 & 0.42 & -1.35 & 0.339 & 48 & 39 & 1.45 & 0.93 & -2.26 & 0.098 & 0.078 \\
\hline Birth weight & & & & & & & & & & & & & & & & & & & \\
\hline$<2.5 \mathrm{Kg}$ & 74 & 61 & 1.27 & 0.89 & -1.83 & 0.189 & 28 & 22 & 1.06 & 0.59 & -1.92 & 0.848 & 46 & 39 & 1.42 & 0.90 & -2.23 & 0.132 & \\
\hline $2.5-3.9 \mathrm{Kg}$ & 987 & 1074 & 1.00 & & & & 381 & 346 & 1.00 & & & & 606 & 728 & 1.00 & & & & \\
\hline$>3.9 \mathrm{Kg}$ & 157 & 164 & 1.05 & 0.82 & -1.33 & 0.721 & 56 & 53 & 0.95 & 0.63 & -1.43 & 0.793 & 101 & 111 & 1.10 & 0.82 & -1.49 & 0.522 & \\
\hline not known & 320 & 320 & 1.16 & 0.96 & -1.41 & 0.129 & 75 & 64 & 1.07 & 0.74 & -1.56 & 0.723 & 245 & 256 & 1.20 & 0.96 & -1.50 & 0.108 & \\
\hline trend & & & 0.95 & 0.78 & -1.16 & 0.616 & & & 0.94 & 0.68 & -1.31 & 0.726 & & & 0.96 & 0.75 & -1.22 & 0.715 & 0.806 \\
\hline Prepubertal height & & & & & & & & & & & & & & & & & & & \\
\hline shorter than average & 237 & 258 & 1.00 & 0.82 & -1.23 & 0.971 & 83 & 87 & 0.83 & 0.58 & -1.18 & 0.295 & 154 & 171 & 1.11 & 0.86 & -1.43 & 0.436 & \\
\hline average & 834 & 912 & 1.00 & & & & 296 & 252 & 1.00 & & & & 538 & 660 & 1.00 & & & & \\
\hline taller than average & 460 & 442 & 1.15 & 0.98 & -1.36 & 0.094 & 160 & 145 & 0.97 & 0.72 & -1.29 & 0.811 & 300 & 297 & 1.26 & 1.03 & -1.54 & 0.027 & 0.218 \\
\hline Prepubertal weight & & & & & & & & & & & & & & & & & & & \\
\hline thinner than average & 693 & 614 & 1.34 & 1.14 & -1.57 & $<0.001$ & 215 & 169 & 1.11 & 0.83 & -1.48 & 0.475 & 478 & 445 & 1.46 & 1.20 & -1.78 & $<0.001$ & \\
\hline average & 583 & 670 & 1.00 & & & & 222 & 188 & 1.00 & & & & 361 & 482 & 1.00 & & & & \\
\hline heavier than average & 255 & 328 & 0.84 & 0.69 & -1.04 & 0.106 & 101 & 124 & 0.64 & 0.46 & -0.90 & 0.010 & 154 & 204 & 0.99 & 0.76 & -1.28 & 0.922 & 0.095 \\
\hline Age at menarche & & & & & & & & & & & & & & & & & & & \\
\hline$<13$ years & 678 & 688 & 1.00 & & & & 251 & 215 & 1.00 & & & & 427 & 473 & 1.00 & & & & \\
\hline 13 years & 392 & 393 & 1.07 & 0.87 & - 1.32 & 0.535 & 148 & 132 & 1.02 & 0.75 & -1.38 & 0.919 & 244 & 261 & 1.07 & 0.86 & -1.35 & 0.539 & \\
\hline$>13$ years & 469 & 540 & 0.97 & 0.80 & -1.19 & 0.785 & 141 & 138 & 0.94 & 0.69 & -1.27 & 0.685 & 328 & 402 & 0.97 & 0.79 & -1.19 & 0.762 & \\
\hline trend per year & & & 1.00 & 0.90 & $\begin{array}{l}-1.11 \\
\end{array}$ & 0.967 & & & 1.00 & 0.92 & -1.10 & 0.948 & & & 0.98 & 0.93 & -1.04 & 0.489 & 0.959 \\
\hline
\end{tabular}


Table 3: Association between birth and childhood characteristics and breast cancer risk by tumor subtype

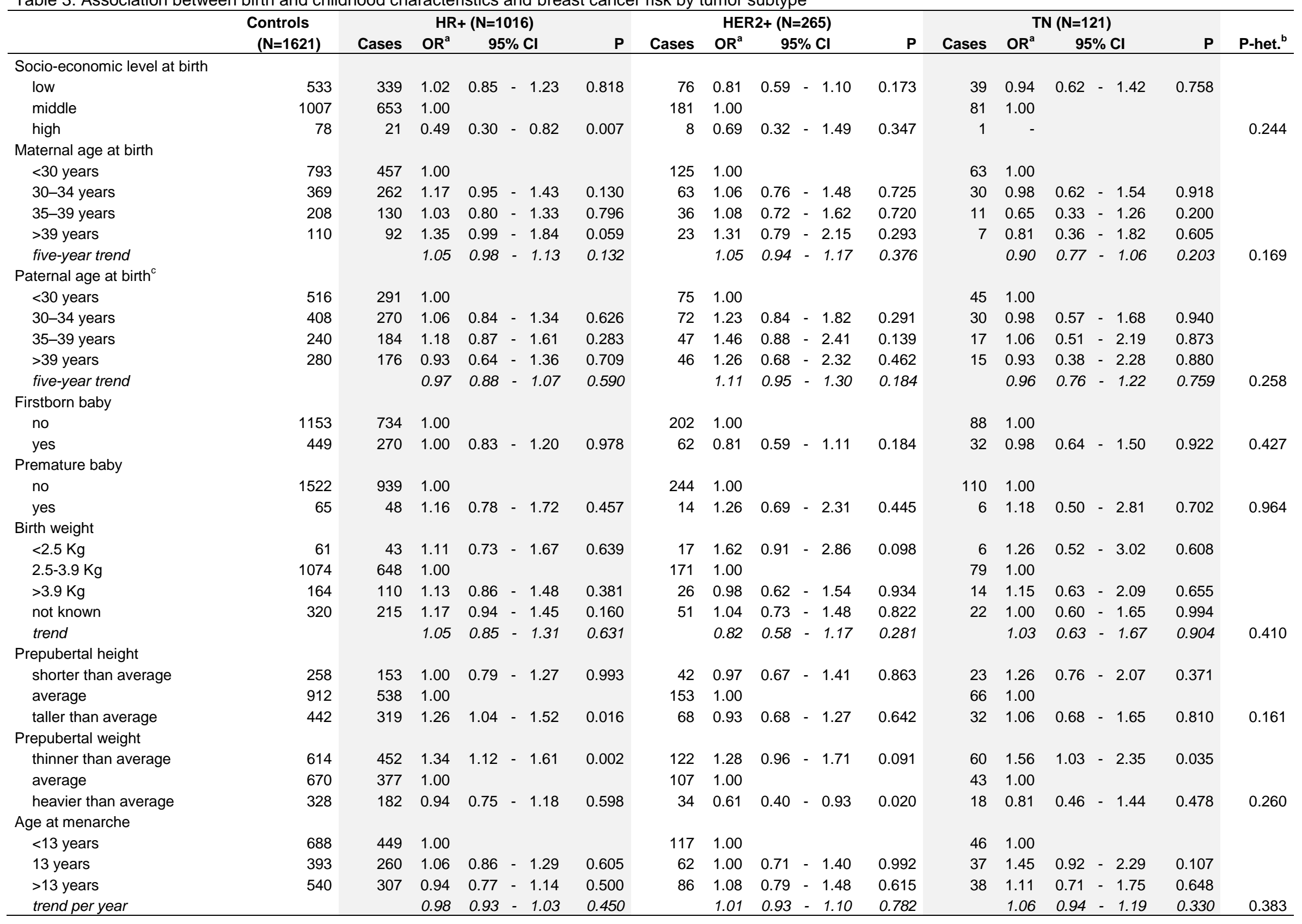


${ }^{a} \mathrm{OR}$ and $95 \% \mathrm{Cl}$ adjusted for age, study level, BMl 1-year before the interview, age at first birth, previous biopsies, family history of breast cancer, age at menarche and menopausal status ${ }^{b} \mathrm{P}$-het.: $\mathrm{P}$ value of heterogeneity of effect between pathologic subtypes

${ }^{c}$ Additionally adjusted by maternal age at birth

In italics: ORs, $95 \% \mathrm{Cl}$ and $\mathrm{P}$ values obtained with the corresponding variable as a continuous term 


\section{Discussion}

This paper examines the association between recalled perinatal and childhood factors and BC in the adult stage, and evaluates whether these effects differ by menopausal status and tumor subtype. As main results we can highlight the increased risk of $\mathrm{HR}+$ tumors associated with advanced maternal age at birth and the inverse association with prepubertal weight among all tumor subtypes.

One of the main strengths of this study is the use of histologically confirmed incident cases, as well as its substantial sample size, since it is the largest epidemiological study to date that analyses the association between $\mathrm{BC}$ risk and perinatal and childhood factors in the Spanish population. This is a multicenter study carried out in 10 Spanish provinces located throughout the Spanish geography covering rural and urban areas and accounting for $42 \%$ of the Spanish women according to the 2011 census [22]. Furthermore, it has been possible to evaluate potential interactions by menopausal status and explore possible differences by tumor subtypes. On the other hand, the statistical models used in this study included a random province-specific intercept term, which accounted for unexplained heterogeneity across different regions.

Several limitations should also be addressed. First, the explanatory variables of interest are self-reported and so they are subject to possible recall bias. However, if recall bias exists, it would probably be non-differential, thus implying an underestimation of the effects studied. To minimize recall error, the questionnaire included comparative measures, which are easier to recall than absolute measures. Furthermore, to recall prepubertal height and weight we also used visual body silhouettes, which have been validated as a reliable self-reported measure of adolescent body size [23], and we have found a high correlation between these two questions (Spearman's coefficient of 0.596; $p$-value $<0.0001)$. On the other hand, these same questions were used in a previous published study [24] where we analyzed the influence of certain childhood-related variables on mammographic density in adult women, and we also detected an inverse association with prepubertal weight and a positive association with prepubertal height and with advanced maternal age at birth. Regarding a potential selection bias, we intended to recruit all cases with a first diagnosis of $\mathrm{BC}$ in the selected health areas, ensuring that very few incident cases were missed in the study. We could not use population cancer registries since in most of these regions there was not any such registry. Third, even though most established risk factors were taken into account in the present study, other unmeasured confounders may influence these associations. For example, alcohol consumption and diabetes were not considered here and according to the Spanish National Health Survey [25] , they are not equally distributed in the areas of the study. However, these and other unmeasured characteristics with a geographical distribution have 
been at least partly accounted for through the random province term. Finally, we were limited by the small size when evaluating certain subgroup associations. This limitation hampered the analysis by BC subtypes, given the low frequency of TN tumors in our context.

Our results show an almost significant increased risk of $\mathrm{HR}+\mathrm{BC}$ among women born to older mothers (>39 years). Several previous systematic reviews have described a positive association with maternal age at birth, although there is heterogeneity among studies $[8,9,14,26]$. Similarly to the prospective cohort study published by Xue et al [27], we have detected a stronger association among postmenopausal women and among women with $\mathrm{HR}+$ tumors. Mother's age at birth has also been associated with higher mammorgraphic density [24], the most reliable phenotype risk marker for BC. These results would support the hypothesis that increased concentrations of endogenous hormones during pregnancy can alter BC risk in daughters [28]. However, the association between maternal age at birth and serum estrogen levels is not consistent; while some studies have reported no association [29, 30], others have found higher serum estrogen concentrations [31], higher bioavailability for estradiol [32] or higher levels of estrogen metabolites [33] among younger mothers. Finally, Panagiotopoulou et al. detected higher estradiol concentrations among mothers belonging to an intermediate age group [34].

Other hormones that seem to play a role in the intrauterine origin of BC are sex hormone-binding globulin (SHBG), insulin-like growth factor I (IGF-1), insulin-like growth factor II (IGF-2) [35] and androgens [36]. However, there are few studies linking these hormones with age at pregnancy. Chen et al [37] detected higher serum IGF-1 and IGF-2 levels in younger mothers during their first trimester, whereas Troisi et al [31] found higher androgen concentrations in these women. So, with the available data there is uncertainty about to what extent maternal age at pregnancy is a marker of hormonal exposure in utero. An alternative, non-intrauterine hypothesis is based on maternal mitochondrial oocyte inheritance [38]. Van Noord proposed that maternal age at birth reflects the quality of the mitochondria, with which an individual begins his or her life. From the meiosis-I time onwards, the mtDNA would start to accumulate mutations even in the resting nondividing oocyte, since circular mtDNA lacks protection by histones or the DNA repair system [38].

Most studies analyzing the association between childhood fatness and BC have found an inverse relationship that seems to be stronger among premenopausal women [7, 39-43], although it has also been observed in the postmenopausal group [7, 40, 41, 44-46]. There are several hypotheses that have been postulated to explain this association. Childhood obesity has been associated with menstrual irregularities, anovulation and higher basal levels of insulin [47, 48]. Insulin acts on various organs to increase sex steroid bioavailability, and this 
overexposure to estrogens in obese prepubertal children could trigger early pubertal development [49-51], increase the expression of tumor suppressor genes (such as BRCA1) and induce early differentiation of mammary epithelial cells, reducing the probability of malignant transformations $[15,52]$. However, no differences were detected in steroid hormone levels by BMI or childhood body shape in some studies [53, 54]. Conversely, an inverse association has been detected between childhood body fatness and adult IGF-1 levels [55, 56], protein which has been associate with an increased risk of $B C$ among premenopausal women $[57,58]$. Finally, reduced progesterone levels have been proposed as a possible explanation for the inverse association between BMI and BC before menopause [59], mainly because this reduction exerts a negative feedback on the hypothalamic pituitary release of gonadotropins.

Although the inverse association between childhood body size and subsequent risk of BC is quite consistent, results by pathologic subtype are not homogenous. Faguerazzi et al only detected an inverse association with ER+ PR+ tumors [60], while Bardia et al described a stronger association with ER+/PR-tumors [44]. On the contrary, Li and Baer found a stronger effect for ER-subtypes [40, 45], and for HER2+ tumors [40]. Finally, Sangaramorthy et al showed no differences by estrogen receptor status [42]. Our results, in consonance with those of Baer and Li [40, 45], show an inverse association more pronounced among HER2+ and TN tumors, supporting an alternative pathway not mediated by sex hormones.

Previous studies have reported a positive association between BC and childhood height or height velocity [12, 13, 61-63]. One possible pathway links height to the number of cells in the body. Larger bodies contain more cells susceptible to undergo malignant transformation [61]. Another explanation is the positive relationship between height and IGF1 levels $[61,64,65]$. In our analyses, the association with prepubertal height was mainly observed among HR+ tumors. This result is in consonance with the second hypothesis, given that the positive association of IGF1 with BC risk seems to be confined to estrogen receptor positive malignancies [66].

Regarding socioeconomic level at birth, while some studies have found no association between BC and paternal occupational level [67] or maternal socioeconomic status [68], others have detected a positive relation with either paternal [69] or maternal education [70]. In the latter study, the effect was mediated by women's adult socioeconomic status and reproductive behaviors, factors that have been taken into account in our analysis. In our case, results are based on a subjective rating made by our participants comparing their families with others around them. Here, the small group of women who reported being born in a high social class had lower risk of BC. Lower socioeconomic status at birth could be a proxy of early-life conditions that could not be controlled for. For example, 
lower parental socioeconomic status is associated with a "western" dietary pattern [71], which has also been linked to $\mathrm{BC}$ risk [72]. On the other hand, women with lower parental education presented higher circulating levels of the inflammation marker C-reactive protein [73] and, therefore higher risk of BC [74].

Previous studies have reported an increased BC risk with heavier birth weight $[8,75]$. However we have not detected an association with this variable, although it should be noted that $21 \%$ of cases and $20 \%$ of controls were unable to answer. On the other hand, earlier age at menarche is consistently linked with an increased risk of premenopausal and postmenopausal BC [76]. However, we found no association, even though Spain is one of the European countries where age at menarche has decreased at a higher rate and since the $50 \mathrm{~s}$ is one of the countries with a lower mean age [77].

In brief, our results suggest an increased $\mathrm{HR}+\mathrm{BC}$ risk associated with advanced maternal age at birth. Furthemore, those women who were taller or thinner than their mates in their prepubertal stage showed higher postmenopausal BC risk, mainly associated with $\mathrm{HR}+$ tumors, while those who were heavier presented lower premenopausal BC risk associated with HER2+ tumors. Some of these perinatal and childhood factors are not easily modifiable. The economic and social changes in recent decades have led to a significant change in the lifestyle of women, such as a considerable delay in the age at first birth. In fact, Spain is the European country with the highest mean age of women at childbirth [78], reaching 32.3 years in 2014 [79]. On the other hand, the inverse association between BC and childhood weight detected in our study should be interpreted with caution in terms of prevention, especially when it is known that obesity is a stablished risk factor for postmenopausal BC [80] and that there is a strong positive association between high childhood BMI and adult obesity [81]. In this sense, Spain is one of the countries with higher risk of adult obesity-related morbidity, since it is the second country in Europe with the highest prevalence of childhood overweight and obesity [82], with 15.5\% of obese girls aged 7-8 years in 2013 [83]. Moreover, according to one study carried out in screening attendants, Spanish women gained an average of $400 \mathrm{~g}$ per year since the age of 18 years [84]. Our results corroborate that early life exposures affect a woman's long-term risk of $\mathrm{BC}$, and hence, prevention efforts should begin earlier in life, targeting potentially modifiable risk factors.

\section{Conflict of interest}

The authors declare no conflict of interest. 


\section{Acknowledgments}

The authors thank all those who took part in this study providing questionnaire data. The authors acknowledge funds provided by the Spanish Ministry of Economy and Competitiveness (Carlos III Institute of Health; PI12/00488, PI12/00265, PI12/01270, PI12/00715, PI12/00150, PI08/1770, PI08/0533, PI08/1359, PS09/00773, PS09/01286, PS09/01903, PS09/02078, PS09/01662, PI11/01403, PI11/01889, PI11/00226, PI11/01810, PI11/02213, PI14/01219 and Rio Hortega CM13/00232), the Catalan Government 2009SGR1489 \& 2014SGR756F, and, by the Fundación Marqués de Valdecilla (API 10/09), by the ICGC International Cancer Genome Consortium CLL, by the Junta de Castilla y León (LE22A10-2), by the Consejería de Salud of the Junta de Andalucía (PI-0571), by the Conselleria de Sanitat of the Generalitat Valenciana (AP 061/10), by the Recercaixa (2010ACUP 00310), by the Regional Government of the Basque Country by European Commission grants FOOD-CT-2006-036224-HIWATE, and by the Spanish Association Against Cancer (AECC) Scientific Foundation.

\section{References}

[1] Ferlay J, Steliarova-Foucher E, Lortet-Tieulent J, Rosso S, Coebergh JW, Comber H, et al. Cancer incidence and mortality patterns in Europe: estimates for 40 countries in 2012. Eur J Cancer 2013;49:1374-403.

[2] Pollan M, Michelena MJ, Ardanaz E, Izquierdo A, Sanchez-Perez MJ, Torrella A. Breast cancer incidence in Spain before, during and after the implementation of screening programmes. Ann Oncol 2010;21 Suppl 3:iii97-102.

[3] Centro Nacional de Epidemiología.Instituto de Salud Carlos III. Mortalidad por cáncer y otras causas en España. Año 2013. http://www.isciii.es/ISCIII/es/contenidos/fd-servicios-cientifico-tecnicos/fd-vigilancias-alertas/fd-epidemiologiaambiental-y-cancer/Mortal2013.pdf

[4] Ekbom A. Growing evidence that several human cancers may originate in utero. Semin Cancer Biol 1998;8:237-44.

[5] Trichopoulos D, Adami HO, Ekbom A, Hsieh CC, Lagiou P. Early life events and conditions and breast cancer risk: from epidemiology to etiology. Int J Cancer 2008;122:481-5.

[6] Colditz GA, Baer HJ, Tamimi RM. Breast Cancer. In: Schottenfeld D, Fraumeni JF, editors. Cancer Epidemiology and Prevention. Third Edition ed. New York: Oxford University Press; 2006. p. 995-1012.

[7] Hankinson S, Tamimi R, Hunter D. Breast Cancer. In: Adami HO, Hunter DJ, Trichopoulos D, editors. Textbook of Cancer Epidemiology. Second Edition ed. New York: Oxford University Press; 2008. p. 403-45.

[8] Park SK, Kang D, McGlynn KA, Garcia-Closas M, Kim Y, Yoo KY, et al. Intrauterine environments and breast cancer risk: meta-analysis and systematic review. Breast Cancer Res 2008;10:R8.

[9] Xue F, Michels KB. Intrauterine factors and risk of breast cancer: a systematic review and meta-analysis of current evidence. Lancet Oncol 2007;8:1088-100.

[10] Rudel RA, Fenton SE, Ackerman JM, Euling SY, Makris SL. Environmental exposures and mammary gland development: state of the science, public health implications, and research recommendations. Environ Health Perspect 2011;119:1053-61.

[11] Russo J, Hu YF, Silva ID, Russo IH. Cancer risk related to mammary gland structure and development. Microsc Res Tech 2001;52:204-23.

[12] Ahlgren M, Melbye M, Wohlfahrt J, Sorensen TI. Growth patterns and the risk of breast cancer in women. N Engl J Med 2004;351:1619-26. 
[13] De Stavola BL, dos SS, I, McCormack V, Hardy RJ, Kuh DJ, Wadsworth ME. Childhood growth and breast cancer. Am J Epidemiol 2004;159:671-82.

[14] Forman MR, Cantwell MM, Ronckers C, Zhang Y. Through the looking glass at early-life exposures and breast cancer risk. Cancer Invest 2005;23:609-24.

[15] Hilakivi-Clarke L, Forsen T, Eriksson JG, Luoto R, Tuomilehto J, Osmond C, et al. Tallness and overweight during childhood have opposing effects on breast cancer risk. Br J Cancer 2001;85:1680-4.

[16] Ruder EH, Dorgan JF, Kranz S, Kris-Etherton PM, Hartman TJ. Examining breast cancer growth and lifestyle risk factors: early life, childhood, and adolescence. Clin Breast Cancer 2008;8:334-42.

[17] Althuis MD, Fergenbaum JH, Garcia-Closas M, Brinton LA, Madigan MP, Sherman ME. Etiology of hormone receptordefined breast cancer: a systematic review of the literature. Cancer Epidemiol Biomarkers Prev 2004;13:1558-68.

[18] Yang XR, Sherman ME, Rimm DL, Lissowska J, Brinton LA, Peplonska B, et al. Differences in risk factors for breast cancer molecular subtypes in a population-based study. Cancer Epidemiol Biomarkers Prev 2007;16:439-43.

[19] Castano-Vinyals G, Aragones N, Perez-Gomez B, Martin V, Llorca J, Moreno V, et al. Population-based multicasecontrol study in common tumors in Spain (MCC-Spain): rationale and study design. Gac Sanit 2015.

[20] Rabe-Hesketh S, Skrondal A, Pickles A. Generalized Linear latent and Mixed Models. http://www.gllamm.org/

[21] Puig-Vives M, Sanchez MJ, Sanchez-Cantalejo J, Torrella-Ramos A, Martos C, Ardanaz E, et al. Distribution and prognosis of molecular breast cancer subtypes defined by immunohistochemical biomarkers in a Spanish populationbased study. Gynecol Oncol 2013;130:609-14.

[22] Instituto Nacional de Estadística. Censos de Población y Viviendas 2011. Resultados Nacionales, por Comunidades Autónomas y Provincias. INEBASE 2015. http://www.ine.es/jaxi/menu.do?type=pcaxis\&path=/t20/e244/avance/p01/\&file=pcaxis

[23] Must A, Phillips SM, Naumova EN, Blum M, Harris S, Dawson-Hughes B, et al. Recall of early menstrual history and menarcheal body size: after 30 years, how well do women remember? Am J Epidemiol 2002;155:672-9.

[24] Lope V, Perez-Gomez B, Moreno MP, Vidal C, Salas-Trejo D, Ascunce N, et al. Childhood factors associated with mammographic density in adult women. Breast Cancer Res Treat 2011;130:965-74.

[25] Instituto Nacional de Estadística. Encuesta Nacional de Salud 2011-2012. INEBASE 2015. http://www.ine.es/jaxi/menu.do?type=pcaxis\&path=/t15/p419\&file=inebase \&L=0

[26] Okasha M, McCarron P, Gunnell D, Smith GD. Exposures in childhood, adolescence and early adulthood and breast cancer risk: a systematic review of the literature. Breast Cancer Res Treat 2003;78:223-76.

[27] Xue F, Colditz GA, Willett WC, Rosner BA, Michels KB. Parental age at delivery and incidence of breast cancer: a prospective cohort study. Breast Cancer Res Treat 2007;104:331-40.

[28] Trichopoulos D. Hypothesis: does breast cancer originate in utero? Lancet 1990;335:939-40.

[29] Kaijser M, Jacobsen G, Granath F, Cnattingius S, Ekbom A. Maternal age, anthropometrics and pregnancy oestriol. Paediatr Perinat Epidemiol 2002;16:149-53.

[30] Troisi R, Potischman N, Roberts J, Siiteri P, Daftary A, Sims C, et al. Associations of maternal and umbilical cord hormone concentrations with maternal, gestational and neonatal factors (United States). Cancer Causes Control 2003;14:347-55.

[31] Troisi R, Hoover RN, Thadhani R, Hsieh CC, Sluss P, Ballard-Barbash R, et al. Maternal, prenatal and perinatal characteristics and first trimester maternal serum hormone concentrations. Br J Cancer 2008;99:1161-4.

[32] Hankinson SE, Colditz GA, Hunter DJ, Manson JE, Willett WC, Stampfer MJ, et al. Reproductive factors and family history of breast cancer in relation to plasma estrogen and prolactin levels in postmenopausal women in the Nurses' Health Study (United States). Cancer Causes Control 1995;6:217-24.

[33] Fortner RT, Hankinson SE, Schairer C, Xu X, Ziegler RG, Eliassen AH. Association between reproductive factors and urinary estrogens and estrogen metabolites in premenopausal women. Cancer Epidemiol Biomarkers Prev 2012;21:959-68. 
[34] Panagiotopoulou K, Katsouyanni K, Petridou E, Garas Y, Tzonou A, Trichopoulos D. Maternal age, parity, and pregnancy estrogens. Cancer Causes Control 1990;1:119-24.

[35] Lagiou P, Samoli E, Okulicz W, Xu B, Lagiou A, Lipworth L, et al. Maternal and cord blood hormone levels in the United States and China and the intrauterine origin of breast cancer. Ann Oncol 2010.

[36] Troisi R, Potischman N, Hoover RN. Exploring the underlying hormonal mechanisms of prenatal risk factors for breast cancer: a review and commentary. Cancer Epidemiol Biomarkers Prev 2007;16:1700-12.

[37] Chen T, Lundin E, Grankvist K, Zeleniuch-Jacquotte A, Wulff M, Afanasyeva Y, et al. Maternal hormones during early pregnancy: a cross-sectional study. Cancer Causes Control 2010;21:719-27.

[38] van Noord PA. An alternative, non-intrauterine hypothesis, based on maternal mitochondrial oocyte inheritance, to explain inconsistent findings of birth weight on (breast) cancer risk. Br J Cancer 2003;88:1817-8.

[39] Magnusson CM, Roddam AW, Pike MC, Chilvers C, Crossley B, Hermon C, et al. Body fatness and physical activity at young ages and the risk of breast cancer in premenopausal women. Br J Cancer 2005;93:817-24.

[40] Baer HJ, Tworoger SS, Hankinson SE, Willett WC. Body fatness at young ages and risk of breast cancer throughout life. Am J Epidemiol 2010;171:1183-94.

[41] Harris HR, Tamimi RM, Willett WC, Hankinson SE, Michels KB. Body size across the life course, mammographic density, and risk of breast cancer. Am J Epidemiol 2011;174:909-18.

[42] Sangaramoorthy M, Phipps Al, Horn-Ross PL, Koo J, John EM. Early-life factors and breast cancer risk in Hispanic women: the role of adolescent body size. Cancer Epidemiol Biomarkers Prev 2011;20:2572-82.

[43] Fuemmeler BF, Pendzich MK, Tercyak KP. Weight, dietary behavior, and physical activity in childhood and adolescence: implications for adult cancer risk. Obes Facts 2009;2:179-86.

[44] Bardia A, Vachon CM, Olson JE, Vierkant RA, Wang AH, Hartmann LC, et al. Relative weight at age 12 and risk of postmenopausal breast cancer. Cancer Epidemiol Biomarkers Prev 2008;17:374-8.

[45] Li J, Humphreys K, Eriksson L, Czene K, Liu J, Hall P. Effects of childhood body size on breast cancer tumour characteristics. Breast Cancer Res 2010;12:R23.

[46] Magnusson C, Baron J, Persson I, Wolk A, Bergstrom R, Trichopoulos D, et al. Body size in different periods of life and breast cancer risk in post-menopausal women. Int J Cancer 1998;76:29-34.

[47] Stoll BA. Teenage obesity in relation to breast cancer risk. Int J Obes Relat Metab Disord 1998;22:1035-40.

[48] Tehard B, Kaaks R, Clavel-Chapelon F. Body silhouette, menstrual function at adolescence and breast cancer risk in the E3N cohort study. Br J Cancer 2005;92:2042-8.

[49] Ahmed ML, Ong KK, Dunger DB. Childhood obesity and the timing of puberty. Trends Endocrinol Metab 2009;20:23742.

[50] Baer HJ, Colditz GA, Rosner B, Michels KB, Rich-Edwards JW, Hunter DJ, et al. Body fatness during childhood and adolescence and incidence of breast cancer in premenopausal women: a prospective cohort study. Breast Cancer Res 2005;7:R314-R325.

[51] Jasik CB, Lustig RH. Adolescent obesity and puberty: the "perfect storm". Ann N Y Acad Sci 2008;1135:265-79.

[52] Cabanes A, Wang M, Olivo S, deAssis S, Gustafsson JA, Khan G, et al. Prepubertal estradiol and genistein exposures up-regulate BRCA1 mRNA and reduce mammary tumorigenesis. Carcinogenesis 2004;25:741-8.

[53] Baer HJ, Colditz GA, Willett WC, Dorgan JF. Adiposity and sex hormones in girls. Cancer Epidemiol Biomarkers Prev 2007;16:1880-8.

[54] Tworoger SS, Eliassen AH, Missmer SA, Baer H, Rich-Edwards J, Michels KB, et al. Birthweight and body size throughout life in relation to sex hormones and prolactin concentrations in premenopausal women. Cancer Epidemiol Biomarkers Prev 2006;15:2494-501.

[55] Poole EM, Tworoger SS, Hankinson SE, Schernhammer ES, Pollak MN, Baer HJ. Body size in early life and adult levels of insulin-like growth factor 1 and insulin-like growth factor binding protein 3. Am J Epidemiol 2011;174:642-51. 
[56] Schernhammer ES, Tworoger SS, Eliassen AH, Missmer SA, Holly JM, Pollak MN, et al. Body shape throughout life and correlations with IGFs and GH. Endocr Relat Cancer 2007;14:721-32.

[57] Hankinson SE, Willett WC, Colditz GA, Hunter DJ, Michaud DS, Deroo B, et al. Circulating concentrations of insulinlike growth factor-I and risk of breast cancer. Lancet 1998;351:1393-6.

[58] Renehan AG, Zwahlen M, Minder C, O'dwyer ST, Shalet SM, Egger M. Insulin-like growth factor (IGF)-I, IGF binding protein-3, and cancer risk: systematic review and meta-regression analysis. Lancet 2004;363:1346-53.

[59] Dowsett M, Folkerd E. Reduced progesterone levels explain the reduced risk of breast cancer in obese premenopausal women: a new hypothesis. Breast Cancer Res Treat 2015;149:1-4.

[60] Fagherazzi G, Vilier A, Boutron-Ruault MC, Clavel-Chapelon F, Mesrine S. Height, sitting height and leg length in relation with breast cancer risk in the E3N cohort. Cancer Epidemiol Biomarkers Prev 2012.

[61] Gunnell D, Okasha M, Smith GD, Oliver SE, Sandhu J, Holly JM. Height, leg length, and cancer risk: a systematic review. Epidemiol Rev 2001;23:313-42.

[62] Li Cl, Littman AJ, White E. Relationship between age maximum height is attained, age at menarche, and age at first full-term birth and breast cancer risk. Cancer Epidemiol Biomarkers Prev 2007;16:2144-9.

[63] Whitley E, Martin RM, Smith GD, Holly JM, Gunnell D. Childhood stature and adult cancer risk: the Boyd Orr cohort. Cancer Causes Control 2009;20:243-51.

[64] Juul A, Bang P, Hertel NT, Main K, Dalgaard P, Jorgensen K, et al. Serum insulin-like growth factor-I in 1030 healthy children, adolescents, and adults: relation to age, sex, stage of puberty, testicular size, and body mass index. $J$ Clin Endocrinol Metab 1994;78:744-52.

[65] Rogers I, Metcalfe C, Gunnell D, Emmett P, Dunger D, Holly J. Insulin-like growth factor-I and growth in height, leg length, and trunk length between ages 5 and 10 years. J Clin Endocrinol Metab 2006;91:2514-9.

[66] Key TJ, Appleby PN, Reeves GK, Roddam AW. Insulin-like growth factor 1 (IGF1), IGF binding protein 3 (IGFBP3), and breast cancer risk: pooled individual data analysis of 17 prospective studies. Lancet Oncol 2010;11:530-42.

[67] de Kok IM, van Lenthe FJ, Avendano M, Louwman M, Coebergh JW, Mackenbach JP. Childhood social class and cancer incidence: results of the globe study. Soc Sci Med 2008;66:1131-9.

[68] Ekbom A, Trichopoulos D, Adami HO, Hsieh CC, Lan SJ. Evidence of prenatal influences on breast cancer risk. Lancet 1992;340:1015-8.

[69] Titus-Ernstoff L, Egan KM, Newcomb PA, Ding J, Trentham-Dietz A, Greenberg ER, et al. Early life factors in relation to breast cancer risk in postmenopausal women. Cancer Epidemiol Biomarkers Prev 2002;11:207-10.

[70] Pudrovska T, Anikputa B. The role of early-life socioeconomic status in breast cancer incidence and mortality: unraveling life course mechanisms. J Aging Health 2012;24:323-44.

[71] Ambrosini GL, Oddy WH, Robinson M, O'Sullivan TA, Hands BP, de Klerk NH, et al. Adolescent dietary patterns are associated with lifestyle and family psycho-social factors. Public Health Nutr 2009;12:1807-15.

[72] Castello A, Pollan M, Buijsse B, Ruiz A, Casas AM, Baena-Canada JM, et al. Spanish Mediterranean diet and other dietary patterns and breast cancer risk: case-control EpiGEICAM study. Br J Cancer 2014;111:1454-62.

[73] Phillips JE, Marsland AL, Flory JD, Muldoon MF, Cohen S, Manuck SB. Parental education is related to C-reactive protein among female middle-aged community volunteers. Brain Behav Immun 2009;23:677-83.

[74] Guo YZ, Pan L, Du CJ, Ren DQ, Xie XM. Association between C-reactive protein and risk of cancer: a meta-analysis of prospective cohort studies. Asian Pac J Cancer Prev 2013;14:243-8.

[75] Xu X, Dailey AB, Peoples-Sheps M, Talbott EO, Li N, Roth J. Birth weight as a risk factor for breast cancer: a metaanalysis of 18 epidemiological studies. J Womens Health (Larchmt ) 2009;18:1169-78.

[76] Menarche, menopause, and breast cancer risk: individual participant meta-analysis, including 118964 women with breast cancer from 117 epidemiological studies. Lancet Oncol 2012;13:1141-51.

[77] Onland-Moret NC, Peeters PH, van Gils CH, Clavel-Chapelon F, Key T, Tjonneland A, et al. Age at menarche in relation to adult height: the EPIC study. Am J Epidemiol 2005;162:623-32. 
[78] Mean age of women at childbirth. Eurostat 2015.

http://ec.europa.eu/eurostat/tgm/table.do?tab=table\&init=1\&language=en\&pcode=tps00017\&plugin=1

[79] Instituto Nacional de Estadística. Movimiento Natural de la Población. (Nacimientos, Defunciones y Matrimonios). Indicadores Demográficos Básicos. Año 2014. Datos provisionales. http://www.ine.es/prensa/np915.pdf

[80] World Cancer Research Fund / American Institute for Cancer Research. Continuous Update Project Report. Food, Nutrition, Physical Activity, and the Prevention of Breast Cancer. 2010. WCRF/AICR 2010. http://wcrf.org/sites/default/files/Breast-Cancer-2010-Report.pdf

[81] Simmonds M, Burch J, Llewellyn A, Griffiths C, Yang H, Owen C, et al. The use of measures of obesity in childhood for predicting obesity and the development of obesity-related diseases in adulthood: a systematic review and metaanalysis. Health Technol Assess 2015;19:1-336.

[82] Wijnhoven TM, van Raaij JM, Spinelli A, Starc G, Hassapidou M, Spiroski I, et al. WHO European Childhood Obesity Surveillance Initiative: body mass index and level of overweight among 6-9-year-old children from school year 2007/2008 to school year 2009/2010. BMC Public Health 2014;14:806.

[83] Estudio ALADINO 2013: Estudio de Vigilancia del Crecimiento, Alimentación, Actividad Física, Desarrollo Infantil y Obesidad en España. 2013. http://www.ciberobn.es/media/434027/estudio aladino 2013.pdf

[84] Pollan M, Lope V, Miranda-Garcia J, Garcia M, Casanova F, Sanchez-Contador C, et al. Adult weight gain, fat distribution and mammographic density in Spanish pre- and post-menopausal women (DDM-Spain). Breast Cancer Res Treat 2012;134:823-38. 